\title{
Two Green Poets: A Comparative Ecocritical Study of Sepehri and Emerson
}

\author{
Behnam Mirzababazadeh Fomeshi, Farideh Pourgiv \\ Department of Foreign Languages and Linguistics, Faculty of Humanities, Shiraz University, Shiraz, IRAN. \\ e-mails: behnam.mirzababazadeh@gmail.com, f.pourgiv@gmail.com
}

\begin{abstract}
Many similar subjects can be traced in world literature, among them is nature since it belongs to man/nature binary opposition. The American poet and philosopher, Ralph Waldo Emerson (1803-1882) employs nature in his works. Throughout his works, he discusses the affinity between man and nature, emphasizing how man takes advantage of it. The contemporary Iranian poet, Sohrab Sepehri (1928-1980), also makes intensive use of nature in his poems. Sepehri is proficient in using nature either in philosophical or emotional issues. Due to the significance of nature in the works or the two figures, an ecocritical reading of them is not only applicable but unavoidable. This comparative study aims at investigating different approaches towards nature employed by the two poets, emphasizing their points of difference. Although both poets employ nature in their works with romantic tendencies, the postmodern environmental ethics of Sepehri is in direct contrast to the instrumental value viewpoint held by his American counterpart.
\end{abstract}

Keywords: Comparative study, Sepehri, Emerson, ecocriticism, intrinsic value, instrumental value

\section{INTRODUCTION}

Many similar subjects can be traced in world literature. Nature is one of them because it belongs to the binary opposition of man/nature. Nature is employed by many artists as a subject for artistic creation. This similarity, in its turn, leads to some differences. There are many works with the same subject, while they enjoy fundamental differences because of their dissimilar themes. Literature is the question of the themes, not the subjects. The similarity in subject is the starting point of this paper to lead to some differences in themes.

The contemporary Iranian poet, Sohrab Sepehri (1928-1980), employed this subject in his poems. Many good instances of employing nature can be found even in his first book, The Death of Color (1951), which did not enjoy nature as much as his later books. His interest in nature increased along with his tendency to Buddhism. Sepehri was proficient in using nature either in philosophical or emotional issues.

The American poet and philosopher, Ralph Waldo Emerson (1803-1882) also enjoyed employing nature in his works. In his journal for 1833, Emerson's first reference to an essay on nature occurred. He was a principal character in the American traditions of ecologically-oriented literature. Emerson, along with Thoreau, "combined the ideas of European Romanticism, Native American culture, and Eastern Philosophy to reconsider the relationship that humans had with the rest of the environment" (Quick, 2004, p. 9), and "brought issues of nature to the forefront of the American consciousness" (Obernesser, 2010, p. 15). Emerson's attitude toward nature is best elaborated in Nature. Throughout his works, the American writer discusses the affinity between man and the nature. According to Emerson, the greatest delight "which the fields and woods minister is the suggestion of an occult relation between man and the vegetable" (as cited in Almansour, 2005, p. 52).

Both figures use nature in their works and have romantic tendencies, but it doesn't mean that they treat the subject in the same way. Employing ecocriticism "as a philosophical and critical discourse and theoretical approach to literary phenomena" (Wang, 2009 , p. 290), this study discusses nature in their writings. This paper may seem in want of a proper methodology, because ecocriticism "is on the whole more issue-driven than methodology-driven" (as cited in Wang, 2009, p. 296). The present paper aims to analyze the approaches of the two figures toward nature and to find the points of similarity and, more importantly, points of difference. 


\section{ECOCRITICISM}

The third millennium has previously perceived the quick yet careful development of a biocentric approach, and attentive to the role of the non-human phenomena in human existence. In the realm of literary criticism the advent of a standpoint called ecological criticism has been observed. Often appreciated as a reasonable improvement out of the field of ecology and accepted as a discrete branch of literary criticism for around ten years now, ecocriticism, draws attention to the affiliation between literary works and the nonhuman environment. It is "one of the responses from literary criticism to the various consequences caused by capitalist modernity. For it has been a tradition for literature to deal with the relations between man and nature, both in the West and East" (Wang, 2009, p. 290).

Eco-critic Glen Love (2003) highlights the significant role that literature can play in raising an ecological and social consciousness when the human survival is endangered. He writes, "the interconnections between human beings and nature...take on a heretofore unprecedented significance at a period when the ...world ....is beset by profound threats of pollution, despoliation and diminishment" (p. 66). Even though it initiates in sixties environmental involvements and texts such as Rachel Carson's Silent Spring (1962) that quickened the movement, ecocriticism is one of the most recent critical approaches.

Even though Rueckert coined "ecocriticism," it was Cheryl Glotfelty who familiarized most literary critics with the approach. Glotfelty insisted on the acceptance of ecocriticism as a respected member of the family of literary studies at 1989 Western Literature Association meeting (Dorbrin \& Weisser, 2002, p. 569). Due to efforts by scholars such as Lawrence Buell, whose groundbreaking 1995 work, The Environmental Imagination: Thoreau, Nature Writing, and the Formation of American Culture, and The Future of Environmental Criticism: Environmental Crisis and Literary Imagination (2005) are among the most cited works in the field, ecocriticism quickly gained significance and reputation.

By 1994, "ecocriticism" had been extensively employed by literary critics, most of whom were still doubtful of the term's precise meaning. From that day on, several researchers, including Buell and Glotfelty, have tried to create a consensus regarding what ecocriticism is (Dorbrin \& Weisser, 2002, p. 569). Buell proposes two definitions of ecocriticism. First of all, he defines ecocriticism briefly "as study of the relation between literature and the environment conducted in a spirit of commitment to environmentalist praxis" (Buell, 1995, p. 430). His second definition of ecocriticism reads as "a multiform inquiry extending to a variety of environmentally focused perspectives more expressive of concern to explore environmental issues searchingly than of fixed dogmas about political solutions" (Buell, 1995, p. 430). A year later, this newcomer in the realm of literary studies is defined by Glotfelty (1996) as,

... the relationship between literature and the physical environment. Just as feminist criticism examines language and literature from a genderconscious perspective, and Marxist criticism brings an awareness of modes of production and economic class to its reading of texts, ecocriticism takes an earth-centered approach to literary studies (p. xviii).

Investigating the "interconnections between nature and culture," this new approach to literature believes that "literature does not float above the material world in some aesthetic ether, but, rather, plays a part in an immensely complex global system in which energy, matter, and ideas interact" (Glotfelty, 1996, p. xix).

What ecocritics do includes re-reading chief works employing a nature-based approach, with specific consideration of the depiction of nature and laying exceptional canonical emphasis on authors who center on nature as an important subject of literary creation, such as Sepehri and Emerson. According to Glotfelty (1996), ecocritics raise a series of questions, including "How is nature represented in this sonnet? What role does the physical setting play in the plot of this novel? Are the values expressed in this play consistent with ecological wisdom? How do our metaphors of the land influence the way we treat it? How can we characterize nature writing as a genre?" (p. xix). They may also raise questions such as "Do men write about nature differently than women do?" and "In what ways has literacy itself affected humankind's relationship to the natural world?" (p. xix).

Although there is not any proof of the connection between eco-criticism and Jacques Derrida's deconstructive thinking, there are "deconstructive fragments in the practice of ecocriticism" (Wang, 2009 , p. 296). Wang tries to depict what the ecocritics have done and what they must do as their vocation.

As humanities scholars and literary critics, the eco-critics have responded first in a critical and aesthetic way. Thus in this sense, the rise of ecocriticism has to a certain extent deconstructed and challenged the mode of anthropocentric thinking. But its final goal should not be merely 
deconstruction, but rather, in the course of deconstruction, construct a sort of new literary environmental ethics (p. 297).

The following part aims at proving that Sepehri succeeded in accomplishing the vocation depicted by Wang.

\section{NATURE IN SEPEHRI}

"Life is the multiplication of the earth by the pulse of our heart."

The Sound of the Water's Step

Sepehri's interest in the natural scenes and his representing lively images of nature enliven his poetry. Many good instances of employing nature can be found even in his first book, The Death of Color (1951), which does not enjoy nature as much as his later books. Hosseini (2000) considers Sepehri a Romantic poet, and then he mentions the glorification of the nature as one of the elements of Romanticism (p. 10). Ashouri et al. (1992) refer to the influence of Far Eastern mysticisms on the poet's interest in nature (p. 26). There are a few poems in which Sepehri does not refer to nature. From 1961 on, and accompanying the publishing of Torrent of Sun, his relation with nature becomes "amorous" (Meghdadi, 1999, p. 122). In this book "penetration into the natural phenomena is one of the central themes" (Dastgheyb, 2006, p. 130). Then his interest in nature increases along with his tendency to Buddhism, and gradually humans are removed from his poetry (Meghdadi, 1999, p. 131). His depiction of nature is not merely for the sake of depiction itself, but he is "looking for a secret" which he does not find in civilized urban life. That is why he takes refuge in nature (Torabi, 2010, p. 236).

In the introduction of his fourth book, Torrent of Sun, he distinguishes between western science and eastern wisdom. While the former tames nature, the latter creates harmony between man and nature (as cited in Torabi, 2010, p. 240). From the writing of "The Sound of the Water's Step" on, nature becomes the theme of his poetry (Ramshini, 2006, p. 105). According to Daneshvar (as cited in Seyyedi, 2005), Sepehri does not depict nature as it is, but as it should be (p. 214). Dastgheyb (2006) calls him "a neighbor" to European artists like Theocritus, who wrote pastoral poems (p. 134).

Animism can be traced in poetry of Sepehri. Garrard (2004) in the glossary of the book Ecocriticism defines animism as the "belief that natural objects and phenomena have spirits" (p. 183). Benjamin (1990) believes,
The historic roots of the new environmental absolutism are to be found in a rebirth of Animism, the earliest of all cosmic and religious sentiments, which held that all of nature was alive due to the spirits (anima=soul) that inhabited all objects and lives in nature. All reality (trees, mountains, stones, rivers) was imbued with consciousness and possessed a kind of invisible electricity, or mana, that only medicine men or shamans could release or constrain. (p. 14).

In Persian and Indian mythologies and in every religion, everything is animate (Taslimi, 2008, p. 148). All early civilizations believed in animism. To the early man the entire world was animate, and no nature element is exception to the rule. He regarded them as having souls like his own, and treated them accordingly. (Frazer, 1996, p. 134). In Sepehri, this belief manifests itself through personification and addressing animals, plants, etc. Sepehri employs personification so much that Reyhani (2006) calls Sepehri's poetry "festival of personification" (p. 40). He has a mythological point of view (Esmaeelpour, 2010, p. 62) based on which everything is animate. As Hosseini (2000) writes, for a Romantic poet nature has a spirit; it is animate (p. 13). The poet believes there is no distinction between animate and inanimate beings (Rahmani, 2003, p. 15). In his world, things apparently lifeless are animate (Ashouri et al., 1992, p. 57). In Sepehri's poetry, natural objects are able to do whatever humans can do. They can speak to human and 'people do not exploit a nature that speaks to them' (Duerr as cited in Manes, 1996, p. 16). So the idea of animism leads to not exploiting nature and consequently to preservation of nature.

In his poetry, the stone has modesty (p. 434), a river "dreams" (p. 157), "a jungle breathes" (p. 182), "the earth calls the rain" (p. 189), and "the sound of the intelligence of the plants is heard" (p. 304). In "The Praise" ("Niyayesh") he writes, "The sun feared our face" (p. 193). Sepehri knows a "donkey which understands the grass" (p. 278). This line shows that in his worldview, not only can a donkey, which is symbol of stupidity in Persian culture, understand, but also it understands much more than many bipeds including mankind. He uses "murder" (p. 284) for the destruction of nature. It implies that nature is alive like humans. In "The Traveler" he writes, "You were watching./The wind's mind was moving between the cow and the grass./You were watching/The memento of the black mulberry on the skin of the season" (p. 313 ). The wind and the black mulberry are animate. The former has the mind, and the latter leaves memento. 
For Sepehri nature is animate, and he is unified with it. "In Sohrab's poetry everything is animate and this is what unifies everything" (Taslimi, 2008, p. 148). Distinguishing between environmental writing and ecocritical writing, Glotfelty (1996) writes the former supports the binary opposition of humanity/nature, whereas the latter unifies the two, or at least questions the relationship between them (p. xx). Explicating his "postmodern wilderness philosophy", Oelschlaeger (1991) comments that postmodernism denotes the likelihood of a fresh model that accepts the interdependence of the human and non-human world as a unified whole: "paradigmatic revolution - a profound change in consciousness, however foolish that idea seems - is in the wind, and humankind may be on the brink of a postmodern age," he writes (p. 320). While Sepehri is not a postmodern poet, he has the same idea of interdependence of the human and non-human world as a unified whole. His poetry is an attempt to bridge the gap between humans and nature (Ashouri et al., 1992, p. 80). The attempt is successful; there is no distance between the poet and nature. In his second book, The Life of Dreams, the poet becomes unified with nature (Atashi, 2003, p. 34). The poet believes there is no distinction between a human, a tree, and water (Rahmani, 2003, p. 15); they are in fact one. According to Sepehri (as cited in Savar Sofla, 2010), a poet is the person whose soul is intermingled with nature (pp. 24-25).

In "The Traveler" the poet aspires to join and dissolve in nature. In Torrent of Sun penetration into the natural phenomena is one of the central themes" (Dastgheyb, 2006, p. 130). In his worldview, nature is an integral part of the heavens so he goes to the nature to join to the heavens. In "Near to the Far" ("Nazdike Dorha") he writes, "The pulse was mixing with the humid truths./My perplexity was mixing with the tree./I realized I am near to the heavens" (p. 415). In "From the Waters Onwards" he writes, "Human/In the gentle laziness of a pasture/Was happy with the azure philosophies./ He was thinking in the direction of the bird./His pulse was in harmony with the pulse of the tree" (p. 424). The two previous extracts refer to the unification with the nature through mentioning the harmony between the pulse of the human heart and nature. In "Another Territory" he writes, "we have joined the immortality of the flowers" (p. 167). In "The Lotus" his unification with nature is depicted in the following lines, "The lotus was wrapping my whole life./In its veins it was me who run./Its existence rooted in me,/It was all me" (p. 120).

Sepehri studied far eastern culture and art. His idea of unification may be under the influence of those ideas. In The Blue Room he refers to the idea of unification with nature in far eastern art and writes "analyze and sketch bamboo for ten years so that you become one with it" (Sepehri, 2009, p. 54). The following example reveals the climax of the poet's unification and selfidentification with nature. In "The Light, Me, The Flower, The Water" he writes, "I know that if I root out a grass I will die" (p. 336). Sepehri makes every effort to make humans united with nature (Reyhani, 2006, p. 43). The unification with nature depicted in the previous lines implies the poet's intimacy with nature, and the high position of nature in his ideology. Intrinsic value is the opposite of instrumental value. To those who believe in biocentrism, natural world possesses intrinsic values which must be protected and respected for their own sake independent of humanity. From an instrumental value viewpoint an object or a phenomenon is valuable if it is at the service of humans. For humans lost in the machine life and captive in the walls of cities, nature is like a mine providing him with the raw materials (Ashouri et al., 1992, p. 20). Sepehri is against this selfish attitude toward nature. From his point of view, every natural phenomenon possesses "value in its own right, without reference to human interests" (Garrard, 2004, p. 183) and "the value of non-human forms is independent of the usefulness these may have for narrow human purposes" (Rothenberg, 1989, p. 29).

In "Surah of Watching" he writes, "And I told them/The stone is not the adornment of the mountain/In the same way that the metal is not an ornament on the body of the pick" (p. 374). The poet believes that the root of the stone's and the metal's value is not their function and use for humans; nature has intrinsic value; and it is valuable in itself. His poetry is a critique of those who define the value of nature "only in relation to human interests, usually narrowly economic" (Garrard, 2004,p. 183). The poet decentralizes mankind. It is no longer mankind and his/her interests that define the value of the natural objects. In His poetry "the commonly conceived wall of separation between man and nature - giving to the former more superiority — breaks down totally" (Tafreshi, 2010, p. 82). He chooses not to prefer. According to Ashouri et al (as quoted in Taslimi, 2008), "[h]e does not sacrifice the trees for humans" (p. 147) for, according to Sepehri, each natural object is valuable regardless of its use for humans; it has intrinsic value.

To conclude, in Sepehri's worldview natural objects are able to do whatever humans can do and things apparently lifeless are animate. Animism manifests itself through personification and addressing animals, plants, and others. For Sepehri nature is animate, and he is unified with it. His poetry is an attempt to bridge 
the gap between human and the nature. The attempt is successful; there is no distance between the poet and the nature. He is against the selfish attitude toward nature. From his point of view every natural phenomenon possesses value in its own right, without reference to human interests.

\section{NATURE IN EMERSON}

The flourishing discourse of ecocriticism may be rightly regarded as a cultural project having its ground in the American nature writing tradition of the 19th century, mainly from authors like, Ralph Waldo Emerson, Margaret Fuller, Henry David Thoreau, and John Muir. The first three figurers' celebration of nature and the wilderness in their works Nature (1836), Summer on the Lakes (1843), and Walden (1845) can be taken as the inspiration for American ecocritical literary criticism and ecocentered writings. The essayist and poet, Emerson was the most important and influential representative figure of American Transcendentalism of the $19^{\text {th }}$ century. Acting as a "preacher, poet and philosopher" in the transcendentalist movement, he is regarded as 'one of the most respected nature writers, namely because of his book Man and Nature and his leading role in the creation of the transcendentalism" (Ellis, 2005, p. 22). According to Buell (1973), the three main apprehendsions of the movement are: spirit, nature, and man and one of the central trends in the writing of the period is: "to create nature anew for oneself" (p. 20). For Emerson (1941), nature and poetry are so interweaved that he writes, "My book should smell of pines and resound with the hum of insects. The swallow over my window should interweave that thread or straw he carries in his bill into my web also" (p. 38). In his journal for 1833 Emerson's first reference on nature occurs. Emerson was engaged with the political issues of his day and his use of natural elements has something to do with either history or politics (Cadava, 1997, p. 11).

Emerson's attitude toward nature is best elaborated in "Nature", which began his career as an essayist (Coughran, 2010, p. 15). His now-famous "Nature" is published anonymously three years later, in 1836 . One of the ecocriticism's theoretical deficits is the absence of an agreed upon definition of nature; theorists of the field cannot decide about a consistent and unified answer to the fundamental question "what is nature?" Emerson provides a couple of definitions for nature, a "philosophical" definition and a commonsensical one. The former proposes that nature is "all that is separate from us, all which Philosophy distinguishes as the NOT ME, that is, both nature and art, all other men and my own body must be ranked under this name, NATURE" (Buell, 2005, p. 22). The latter "refers to essences unchanged by man: space, the air, the river, the leaf' (Buell, 2005, p. 22). Then, it is not confined to natural environments, but it also includes a place for human environments. Nature is his earliest most important work, and it continues to be his best known. It begins with "affirmation of our absolute intimacy with" the nature (Smith, 2003, p. 847). The different editions of this work have different epigraphs. "Nature is but an image or imitation of wisdom, the last thing of the soul; Nature being a thing which doth only do, but not know" is the epigraph beginning the 1836 edition. This more poetic epigraph from Plotinus is substituted by one of Emerson's poems in 1849 edition.

The epigraph from Plotinus highlights a widespread theme all through the work. The theme is that nature does not possess a personality by itself. It is human who projects his/her own feeling and thoughts on the nature and grants it with personality. Therefore one can claim Emerson does not believe in animism of nature. Although Emerson's 1836 "Nature" was a "landmark in the American spiritualization of nature" (Clary, 2010, p. 35), to him human consciousness is the preponderate protagonist, but nature is subservient, or at most respondent to human idealism.

According to Emerson, human should keep in touch with nature constantly and experience it directly. This kind of experience is preferred to the study of history and science since one will gain some knowledge through these two disciplines, but the problem is that this kind of knowledge is not genuine since it is not experienced directly. The best way to know nature is to have a touch with nature without any mediator. Emerson felt an urgent need to re-experience nature because humans had missed their original association with the land. He laid emphasis on "relying on personal experience and interaction with nature to inspire individual understanding" (Tovey, 2011, p. 69).

Emerson refers to the dust of familiarity covering the natural objects. Since we are all the time provided with such great advantages of nature we take them for granted and do not appreciate them as we should do. He mentions the stars which we see every night in the sky. He writes we take them for granted then he goes to the immediate context of himself. Therefore he connects the farthest objects with the nearest ones to remind the reader that there is something common to all of the objects of nature that unites them to one another. Emerson believes one of the differences between the poet and an ordinary person is that the former is able to observe nature clearly. It seems that 
he has the idea of familiarity in mind. His Iranian counterpart writes "dust of familiarity is always in the course of watching" (Sepehri, 2009, p. 314). Since we are familiar with an object we are unable to see it in a novel way so we carry with ourselves the old prejudices and impose them on the objects we see. The poet, on the other hand, is the person who gets rid of this familiarity; everything $\mathrm{s} / \mathrm{he}$ sees $\mathrm{s} / \mathrm{he}$ sees for the first time. His/her eyes are "washed" so s/he observes the nature in a new and different way. For Emerson the poet's task is to determine and express "the interconnectedness between humanity, Nature and Divinity" (McDonald, 2009, p. 104) and "the poet and nature are on equal standing, mutually nutritive, and more significant in their divine creations than a single divine "God"' (Travis, 2010, p. 112).

In the chapter entitled "Commodity", Emerson finds the nature useful for human because it provides us with what we need physically. By "commodity" he means material need. It seems nature lacks intrinsic value; it is not valuable by itself. Emerson finds it worth writing about because it is useful, of course for human, so it is the human who is at the center and decides what is valuable or not according to his/her own needs and necessities. He "spoke less emphaticcally of preserving nature or tempering human development of wild areas for the sake of nature itself than they spoke of valuing nature for the spiritual or philosophical enrichment of the individual human" (Quick, 2004, p. 11). As Emerson made clear in "Nature," nature is made to serve. It is compared to an ass receiving the dominion of man. Such an anthropocentric approach to the natural world favors human against non-humans. Through such perspective ecological ethics is ultimately based on man's interests, and so environmental conservation and preservation are reasonable grounded on their significance for human prosperity. Since reason d'etre of nature is human welfare, the preservation of nature is vital less for its intrinsic value than ethical commitments to forthcoming generations.

Emerson is ambivalent toward industrial and technological developments affecting nature. He "could never successfully resolve within himself the debate between Nature and civilization, solitude and society, rusticity and manner" (Miller, 2001, p. 327). If according to Wang (2009), "there are two different attitudes toward nature: either be intimate with nature and even be subject to the changeable temper of nature, or violently to control it and even ruthlessly to conquer or transform it by every means possible" ( $p$. 292), Emerson seems to vacillate between the two.

In the next chapter Emerson writes about beauty. $\mathrm{He}$ believes beauty is one of our needs that nature satisfies. From the physical necessity of the previous chapter he moves to some spiritual and intellectual needs. However, the central position of human and the lack of intrinsic value for the nature still remain. $\mathrm{He}$ considers beauty as a necessary element for the survival, but not as necessary as the physical ones of the previous chapters because the physical necessities precede the beauty in his essay. Beauty is important since it has some uses for human. Emerson considers three uses of beauty of nature for men: healing qualities, spiritual element and intellectual properties. He believes in healing and soothing power of nature which is provided for example while walking in nature. According to Emerson, a moral person is most in accord with nature because nature bestows its favors on the person with the noble thoughts. Emerson believes beauty of the nature is also pleasing to the intellect. Once more he mentions the nature as the foundation of art.

Another use human makes of the nature is language. It is the nature which supplies human with the language. Words are symbols of natural realities. This opinion is not that much favored by recent linguists. Language is fundamental to Emerson's account of the nature and "man in harmony" since it is one of the most important uses man makes of the nature (Ironside, 2009, p. 88). He counts different uses for the nature. The title of each chapter represents one of the uses which the nature provides human with.

The analysis of this essay indicates that Emerson believes in constant and direct touch with nature. $\mathrm{He}$ finds it valuable because it is useful, of course for human. Humans, Emerson says, are paramount over nature. Emerson, throughout Nature, is counting different aims of the nature; he wants to find and end for nature which is at the service of human. In another essay he suggests that "it is the purpose of Nature to serve the farmer" (Lumpkin, 2006, p. 45). As Wilson (2000) believes the essay may develop from matter to spirit, from nature's material uses to its spiritual functions. However, the point is that nature has not any intrinsic value; it is valuable because it is useful for man.

\section{CONCLUSION}

While Emerson believes nature does not have a personality of its own, for Sepehri natural objects are able to do whatever humans can do and things apparently lifeless are animate. For Sepehri nature is animate, and he is unified with it. For Emerson, nature lacks intrinsic value; it is not valuable by itself. Sepehri is against this selfish attitude toward nature. From his point of view every natural phenomenon possesses value in its own right, without reference to 
human interests. Employing Derridaean terminology one can say the poet decentralizes human and deconstructs the long-held binary opposition of man/nature in which the former is superior to the latter. In the course of deconstruction, he "construct[s] a sort of new literary environmental ethics" (Wang, 2009, p. 297); he writes according to a "sort of literary environmental ethics that may well contribute quite a bit to constructing a harmonious society as well as a harmonious world" (p. 290). Borrowing from Wang, one can conclude that Sepehri's environmental ethics is a sort of postmodern environmental ethics characterized by both/and that is in direct contrast to Emerson's modernist environmental ethics of either/or.

\section{REFERENCES}

Waldo Emerson, Nathaniel Hawthorne, and Edgar Allan Poe (Unpublished doctoral dissertation). The Ohio State University, Columbus, CA.

Ashouri, D., Emami, K., \& Hamedani, H. M. (1992). A message on the way. Tehran: Tahouri.

Atashi, M. (2003). Sohrb: The poet of the painters. Tehran:Amitis.

Benjamin, W. (1990). Animism redivivus: Are new visions of nature a threat to homo sapiens? In W. M. Hoffman, R. Frederick, \& E. S. Petry, Jr. (Eds.), The corporation, ethics and the environment (pp. 11-24). Westport: Quorum Books.

Buell, L. (1995). The environmental imagination: Thoreau, nature writing, and the formation of American culture. Cambridge: The Belknap Press.

Buell, L. (1973). Literary transcendentalism: Style and vision in the American Renaissance. Ithaca: Cornell University Press.

Buell, L. (2005). The future of environmental criticism: Environmental crisis and literary imagination. Malden, MA: Blackwell.

Cadava, E. (1997). Emerson and the climates of history. Stanford: Stanford University Press.

Clary, A. (2010). Mark Twain in the desert. Journal of Ecocriticism, 3(1), 29-39.

Coughran, C. (2010). Sub-versions of pastoral: Nature, satire and the subject of ecology. Journal of Ecocriticism, 2(2), 14-29.

Dastgheyb, A. (2006). The green garden of poetry. Tehran: Amitis.

Dorbin, S. I. \& Weisser, C. R. (2002). Breaking ground in ecocomposition: Exploring relationships between discourse and environment. College English, 64, 566-589.

Ellis, J. E. (2005). The legacy of John Muir: Writing to promote ecological preservation and change environmental values (Unpublished doctoral dissertation). Miami University, Oxford, Ohio.
Emerson, R. W. (2010). Nature and other essays. New York: Classic Books International.

Emerson, R. W. (1941). The best of Ralph Waldo Emerson: Essays, poems, addresses. New York: D. Van Nostrand Company.

Esmaeelpour, A. (2010). The reflection of myth in the poetry of Sohrab Sepehri. In S. Savar Sofla (Ed.), Where is the friend's home? (pp. 61-75). Tehran: Sokhan.

Frazer, J. G. (1996). The golden bough: A study in magic and religion (Abridged ed.) London: Penguin.

Garrard, G. (2004). Ecocriticism. New York: Routledge.

Glotfelty, C. (1996). Introduction. In C. Glotfelty, \& $\mathrm{H}$. Fromm (Eds.), The Ecocriticism reader: Landmarks in literary ecology (pp. Xv-xxxvii). Athens: GA UP.

Hosseini, S. (2000). The silent lotus. Tehran: Niloufar. Ironside, F. (2009). Bloom's how to write about Ralph Waldo Emerson. New York: Infobase Publishing.

Love, G. A. (2003). Practical ecocriticism. Charlottesville: University of Virginia Press.

Lumpkin, G. T. (2006). The promise of technology versus the pastoral ideal: Ralph Waldo Emerson's conflict over the role of mankind in nature. International Journal of Humanities and Peace, 22(1), 45-46.

Manes, C. (1996). Nature and silence. In C. Glotfelty and H. Fromm (Eds.), The Ecocriticism reader: Landmarks in literary ecology (pp. 15-29). Athens, Georgia: University of Georgia Press.

McDonald, P. (2009). The funny side of nature: Humor and the reclamation of romantic unity in the 'Dark Poetry' of Bill Hicks. Journal of Ecocriticism 1(2), 104-113.

Meghdadi, B. (1999). Hedayat and Sepehri. Tehran: Hashemi.

Miller, P. (2001). Nature and American nationalism. In D. Mazel (Ed.), A century of early ecocriticism (pp. 314-340). Athens, Georgia: Georgia UP.

Obernesser, S. (2010). Searching for the wild: The changing post-war conceptions of environmentalism and gender (Unpublished master thesis). Bowling Green State University, Bowling Green, $\mathrm{OH}$.

Oelschlaeger, M. (1991). The idea of wilderness: From prehistory to the age of ecology. New Haven: Yale University Press.

Quick, P. S. (2004). An ecocritical approach to the southern novels of Cormac McCarthy (Unpublished doctoral dissertation). The University of Georgia, Athens, GA.

Rahmani, M. (2003). Sohrab: The green poet. Tehran: Alborz. 
Ramshini, M. (2006). Sohrab and Jibran. Mashhad: Farhangsaray-e-Mirdashti.

Reyhani, M. (2006). Sepehri: The interpreter of the old verses. Mashhad: Ahang-e-Ghalam.

Rothenberg, D. (1989). Ecology, community and lifestyle: Outline of an ecosophy. Cambridge, England: Cambridge University Press.

Savar Sofla, S. (2010). Where is the friend's home? Tehran: Sokhan.

Sepehri, S. (2007). The eight books. Tehran: Tahouri.

Sepehri, S. (2009). The blue room. Tehran: Soroush.

Seyyedi, S. H. (2005). To the garden of fellow travellers. Mashhad: Ferdowsi University press.

Smith, D. L. (2003). "The Sphinx must solve her own riddle": Emerson, secrecy, and the self-reflexive method. Journal of the American Academy of the Religion, 71, 835-861.

Tafreshi, A. R. (2010). Stylistic analysis of a poetic text: A case from Persian. Journal of Language and Translation, 1(1), 75-84.
Taslimi, A. (2008). Some propositions in Iranian contemporary literature. Tehran: Akhtaran.

Travis, C. M. (2010) Huidobro's rose: The environmental dialectics of Creacionismo. Hispanic Issues On Line, 6, 93-118. Retrieved from http://hispanicissues.umn.edu/Spring2010/05_H uidobro_Travis.pdf.

Torabi, Z. (2010). Another Sohrab. Tehran: Donyaye-Now.

Tovey, P. E. (2011). Countless cross-fertilizations: Gary Snyder as a post-romantic poet (Unpublished doctoral dissertation). Durham University, Durham.

Wang, N. (2009). Toward a literary environmental ethics: A reflection on eco-criticism. Neohelicon, 36, 289-298.

Wilson, E. (2000). Emerson's Nature, paralogy, and the physics of the sublime. Mosaic: a Journal for the Interdisciplinary Study of Literature, 33(1), 39-58. 